Article

\title{
Untangling the Impact of Green Finance on the Enterprise Green Performance: A Meta-Analytic Approach
}

\author{
Hengjie Xu, Qiang Mei *, Fakhar Shahzad * ${ }^{*}$, Suxia Liu, Xingle Long and Jingjing Zhang \\ School of Management, Jiangsu University, Zhenjiang 212013, China; xhj9582@sina.com (H.X.); \\ suxialiu@yeah.net (S.L.); longxingle@163.com (X.L.); zhjing-ujs@foxmail.com (J.Z.) \\ * Correspondence: qmei@ujs.edu.cn (Q.M.); fshahzad51@yahoo.com (F.S.)
}

Received: 16 October 2020; Accepted: 29 October 2020; Published: 31 October 2020

\begin{abstract}
In recent years, with sustainable development strategies, the conflict between economic development and natural resources has become increasingly severe. Meanwhile, green finance's emergence is due to the rethinking of human economic activities under global warming conditions and the energy crisis. Thus, this study aims to analyze the relationship between green finance and enterprise green performance using a meta-analytic approach. This study has used Comprehensive Meta-Analysis Software (CMA) 2.0 for meta-analysis and applied the Hunter and Schmidt model for statistical analysis to test the proposed hypotheses. This study finds a significant positive correlation between green finance and enterprise green performance and proves that firm type and region play a moderating role in the relationship between green finance and enterprise green performance. However, profitability does not significantly moderate the relationship between green finance and enterprise green performance.
\end{abstract}

Keywords: Green finance; enterprise green performance; meta-analysis

\section{Introduction}

Enterprise is one of the components of the social economy, its primary purpose is to improve efficiency, and it also has a responsibility to protect nature and to serve social groups. With the continuous development of green management, the enterprise goal has changed from the single activity of economic gains to the unity of economic benefits, social benefits, and ecological benefits. Correspondingly, the evaluation of enterprise performance also needs to adapt to such changes. What green performance pursue is the balance between environmental protection and economic development. In addition, the increasing awareness of customer leads to a change of their preference; customers are more likely to choose green products [1]. Moreover, local and international environmental regulations also force enterprises to consider the influence of their operation on nature and follow environmentally-friendly [2].

However, the blind pursuit of environmental protection will affect the economic benefits of enterprises [3]. The financial constraints limit the protection of the environment by a large number of enterprises during production and consumption. Nowadays, the rise of green finance provides enterprises with a new finance method to solve this trouble. Various countries are committed to green finance. In 2005, the United States passed the "new energy law", which provided tens of billions of dollars in tax incentives and subsidies to new energy companies. Japan's "green finance rules" enacted in 2003 offers tax incentives to financial institutions that meet environmental standards. China also layout plans for green financial development. In 2016, the People's Bank of China issued "Guidance on Building a Green Financial System", indicating that green finance had entered a stage of rapid 
development. Although green finance is developing rapidly around the world, the definition is not clear and commonly accepted. The American heritage dictionary (4th Ed., 2000) replaces green finance with "environmental finance" or "sustainable finance". Its essence is to achieve the goal of environmental protection in the market by using various financial instruments. Subsequently, the British government defined green finance as "to develop low-carbon energy, improve energy efficiency, adapt to climate change, and invest in environmental protection and natural resources" [4]. In its most recent report published in 2016, the German development research institute (DIE) defined green finance as "all investments or loans that take into account environmental impacts and enhance environmental sustainability" [5]. Compared with traditional financial activities, green finance pays more attention to ecological and environmental benefits, as well as to environmental protection. It is useful to find an ecological balance from the aspect of both market and policy [6]. Thus, more and more studies begin to summarize the meaning of green finance and prove whether the effect of green finance can improve green performance.

Previous studies have considered whether investment in the environment may reduce profit or not affect environmental protection $[7,8]$, while others consider the cost of environmental protection improves the profitability and green innovation ability $[9,10]$. In addition, the meaning and the dimensions of enterprise green performance are not exact because the prior studies only consider the dimension of environmental performance [11], but nowadays, the meaning of green performance is much more than that. Scholars add economic and green innovation indicators into it, but the findings are controversial. Some research found that environmental regulation and investment are harmful to economic development $[4,11]$, while some found a positive effect on financial performance and green innovation performance [12,13].

Due to the research findings regarding this issue are controversial, which reflect in several empirical research, meta-analysis is an appropriate tool to find a reliable and common conclusion. Therefore, meta-analysis aims to use statistical methods, based on how to perceive the error, to put forward the closest overall estimate of unknown common facts. It is also crucial to fill the existing gap through a meta-analysis of the current literature, which will build a comprehensive understanding of this specific topic. Based on the current literature, this study analyses the effect of green finance on enterprise green performance from 30 studies before 2020 by using meta-analysis and examining whether the moderators (profitability, firm type, and region) can influence this relationship.

In order to clarify the process of results, the other sections in this article organized as follows. Section 2 reviews related literature on the topic of green finance and enterprises' green performance; it explains the positive and negative relationship and explains the moderators of these relationships. Section 3 offers the process of data collection and method, and Section 4 analyses the results of the meta-analysis and provides a detailed discussion. Finally, Section 5 concludes this study and points out the limitation, as well as some further suggestions.

\section{Literature Review and Hypotheses Development}

\subsection{Green Finance}

The emergence of the "equator principle" promoted the green revolution. Since then, the green financial system with the "equator principle" as the standard has been gradually popularized globally. The G20 in 2016 summitted the concept of "Green Finance" received extensive attention from all of society [14]. In practice, as early as the 1980s, the United States enacted the "energy tax law", which provides tax incentives to businesses that develop renewable energy. The Höhne et al. [15] refers to green finance as a financial investment flowing into environmental-friendly projects, sustainable development initiatives, and policies for developing a sustainable economy. The study of [16] defines green finance as a part of the financial system that handles special green investment, such as some financial instruments for green investments. According to International Finance Corporation (IFC) report [17], green finance is defined as "financing of investments that provide environmental benefits". 
Green finance plays an important role at the enterprise level in fostering enterprises environmentally sustainable investments, and it includes financial products for large-scale environmental objectives [18].

The green financial products can be divided into three major parts: retail finance such as green credit, asset finance such as green subsidy and carbon fund, and corporate finance such as green investment and green bond [19]. The development of green credit benefits financial development and reduces the environmental deficiencies of financial development [20]. That is to say, green credit may influence firm financing constraint so that influence firm economic performance. Green investment refers to reducing pollution without significantly reducing the production and consumption of non-energy goods [21]. Accordingly, it may have the purpose of either reducing costs or increasing revenues [22]. Compared to tools based on the market, the green subsidy has higher economic efficiency in solving external environmental problems [23]. Green subsidy policies enacted by governments incentivize firms to develop green production strategies so that firms tend to invest more in green innovation and achieve better environmental performance [24]. In addition, firms can issue a green bond to raise capital to finance their environmental-friendly projects in order to have a positive environmental performance [10]. That is because the issue of a green bond may attract more investors, so that generates more trades on the stock market. Thus, this study aims to identify green finance dimensions as green credit, green bonds, green investment, and green subsidy.

\subsection{Enterprise Green Performance}

The green performance of enterprises emphasizes the effective use and efficient allocation of enterprise resources to reduce or even eliminate the threat and damage to the environment caused by enterprise activities, to achieve long-term efficient operation of enterprises [25]. It always refers to the measurement of the environment in previous studies [11], but nowadays, some scholars believe that green performance indicators should cover both economic and environmental aspects [26]. In empirical studies, many scholars also take economic factors into the evaluation system of green performance. The study of Lirn et al. [27] consider investing in recyclable resources and reducing energy consumption as a green performance indicator. The study Tseng et al. [28] proposes a green performance criterion from the financial aspect, according to gross profit from green products, solvency, and debt financing. Green innovation is also associated with green performance. Companies introduce new technologies to permit them to produce, absorb, develop, and manage products and processes to tackle environmental problems, such as pollution and resource consumption, caused by organizational activities [29].

This paper measures the enterprise green performance as environmental performance, economic sustainability performance, and green innovation performance based on the above analysis. Economic sustainability performance in this paper mainly refers to enterprises' profits or income through their green financial products. In contrast, environmental performance mainly refers to enterprises' achievements in the aspects of resource utilization rate and environmental pollution degree. Green innovations performance refers to advances in products, processes, and management that can lead companies to accomplish sustainable competitive advantages in an eco-effective way [30,31].

\subsection{Hypotheses Development}

\subsubsection{The Effect of Green Finance on Enterprise Green Performance}

A neoclassical theory represented by Walley and Whitehead in 1994 argues that environmental regulation imposes extra fee from firms [32]. They consider pollution control measures will increase production costs, if marginal costs continue to increase, pollution control and environmental performance improvement will reduce marginal net profit. That is, green finance has a negative influence on enterprise green performance $[7,8]$.

However, the neoclassical theory was doubted with the introduction of the Porter Hypothesis. Porter considers appropriate environmental regulations to prompt enterprises to carry out more innovative activities because these innovations will improve enterprises' productivity, thus offset the cost 
of environmental protection and improve the profitability of enterprises in the market [33]. More and more scholars doubt neoclassical theory. The most representative theory is the natural resource-based view and stakeholder theory. The natural resource-based view introduces environmental factors into the resource-based theory's research framework and holds that enterprises can use organizational resources to cope with natural environmental challenges. While bringing competitive advantages to enterprises, it also helps to improve financial performance [34].

According to the stakeholder theory, enterprises can meet the environmental demands of stakeholders and improve the organizational efficiency to adapt to the changes of the external environment, which is conducive to the improvement of corporate reputation and establishment of long-term relationships with suppliers and customers, so that lead to the improvement of financial performance $[35,36]$. That is, green finance has a positive influence on green enterprise performance. Many researchers found the same conclusion. The study of Deng and Lu [9] demonstrated that green finance policy could improve food firms' environmental performance, and the study of Zhou et al. [10] found green finance has a significant positive impact on the environment and economy.

In addition, the studies found a non-linear relationship between these two variables [37,38]. According to the findings above, this study proposed the following hypothesis:

H1. Green finance has a significant positive impact on enterprise green performance.

\subsubsection{Dimensions of Green Finance and Enterprise Green Performance}

Scholars have made many explorations on the relationship between green financial products and enterprise green performance. A study of $\mathrm{He}$ et al. [8] proved green credit has a small promoting effect on the enterprises' performance. Meanwhile, the study of Hu et al. [39] analyzed 97 listed energy-intensive companies in China and concluded that green credit has a significantly positive effect on firms' borrowing ability. Furthermore, study of Nie et al. [40] concluded that government environmental subsidies increase outputs, debt levels, and the shareholder value of renewable energy firms. The study of Gianfrate and Peri [41] found green bonds play a major role in greening the economy. However, some scholars found the opposite conclusions, considered the issuance of green credit does not necessarily improve the enterprise's operational efficiency and financial performance [7]. The study of Fujii et al. [42] proved a significant inverted U-shaped relationship between environmental investment and environmental performance using Japanese manufacturing firms' data. According to the literature above, it seems that different green financial products affect green performance differently. Thus, this study also proposed the following hypotheses:

H2a. Green credit has a significant positive impact on enterprise green performance.

H2b. Green investment has a significant positive impact on enterprise green performance.

H2c. Green subsidy has a significant positive impact on enterprise green performance.

H2d. Green bond has a significant positive impact on enterprise green performance.

\subsubsection{Green Finance and Three Dimensions of Enterprise Green Performance}

Researchers always take environmental performance and economic performance into the indicator system of green performance. For example, Golinska and Kuebler [43] established an evaluation system from the dimensions of economic benefit and environmental benefit to evaluate small and medium-sized enterprises' green development maturity. The empirical study of Antonietti and Marzucchi [22] found green investments combining environmental increases revenue objectives so that they can achieve a higher export performance. The research of Bai et al. [13] found green subsidies promote enterprises' green efficiency and decompositions significantly. However, some researchers found the opposite conclusions. The study of Wang et al. [37] concluded that there is no significant positive correlation between environmental performance and corporate green financing. Also, Pekovic et al. [3] found 
there is an optimal level of environmental investment. Too little or too much environmental effort can be detrimental to enterprise performance.

It is founded that environmental regulations can affect green innovation performance and environmental performance according to the evidence from China's non-ferrous metals industry [12]. In addition, Aguilera-Caracuel and Natalia [44] observed that green innovative firms and non-green innovative firms have different financial performance effects. Similarly, environmental regulation has a positive influence on the green innovation performance of firms. According to the literature above, it seems that green finance's effect on the different dimensions of enterprise green performance is different. Thus, this study proposed the following hypothesis:

H3a. Green finance has a significant positive impact on environmental performance.

H3b. Green finance has a significant positive impact on green innovation performance.

H3c. Green finance has a significant positive impact on economic sustainability performance.

\subsection{Moderating Relationships}

\subsubsection{Profitability}

Profitability evaluation is one of the main contents of financial evaluation; it shows how a company uses its assets to create value and profits for shareholders. There are several ways to measure profitability, but we use the most common method of measuring profitability, e.g., return on assets (ROA) and return on equity (ROE). ROA is defined as "an indicator of how profitable a company is relative to its total assets" [45]. Meanwhile, ROE is defined as "a measure of financial performance calculated by dividing net income by shareholders' equity" [46]. The number of ROA has a positive relationship with the company's management efficiency in dealing with assets, so that reflects firm performance [47]. Moreover, higher ROE indicates a higher ability to generate cash internally for a company. It also can be used to filter companies that have higher profitability in one industry [47]. The profitability analysis can find the problems existing in enterprise management to help enterprises improve financial performance. Financial performance is one of the important parts of green performance. Recently, a research of Pekovic et al. [3] studied the effect of environmental investments on economic performance from more than 6000 French firms over five periods, and they mentioned that ROA might exaggerate relations of interest and confound the interpretation of results. Similarly, Wang et al. mentioned that ROA moderates the relationship between green credit and cooperative investment, according to China's evidence, also concluded by [8,37]. The study of He et al. [8] mentioned that ROE moderates the relationship between green financial development and renewable energy investment efficiency. Based on the existing literature, this study proposed the following hypothesis:

H4. Profitability of enterprise moderates the relationship between green finance and green performance.

\subsubsection{Firm Type}

Firm type can also moderate this relationship. The green finance and green performance are related to the environment, green finance aims to guide sustainable development by financing products [48], and it provides financing facilities for environmentally conscious enterprises [49]. Therefore, environment-friendly enterprises (i.e., renewable energy enterprises) and non-environment-friendly enterprises (i.e., manufacturing enterprises) may have different impacts on the research relationship. For instance, Wang et al. [50] conclude that polluted enterprises are subject to severe constraints under the green credit environment. The study of $\mathrm{He}$ et al. [8] found that the corporate social responsibility of the mining, power, and steel industries in China are promoted by green credit. Meanwhile, Wang et al. [37] demonstrated that the Green Credit Guidelines policy's adverse impact on long-term debt is more evident in heavily polluting companies. Another study of $\mathrm{He}$ et al. [51] investigated 150 
renewable energy listed companies of China; the result shows that green investment promotes the green economy development in China. Therefore, our fourth hypothesis was:

H5. The type of enterprises (i.e., environment-friendly enterprises and non-environment-friendly enterprises) moderates the relationship between green finance and green performance.

\subsubsection{Region}

The difference between countries is another moderator of this study. Cultural traditions, environmental regulations, legislation, and socio-economic context, and these influence corporate social responsibility attitudes are different among countries. In general, European and South American countries put forward green finance earlier than Asian countries. The American heritage dictionary replaces green finance with "environmental finance" or "sustainable finance" [52]. Its essence is to achieve the goal of environmental protection in the market by using various financial instruments. In 2015, "The Overall Plan for Ecological Civilization System Reform" was announced, and the Chinese government recommended the formation of a green financial system for the first time [53]. Because of the different development of green finance in different regions, the influence on enterprises' green performance is probably different. Thus, this study put forward a hypothesis as follows:

H6. The region under study moderates the relationship between green finance and green performance.

According to the above assumptions, this study proposed a research model for testing, shown in Figure 1.

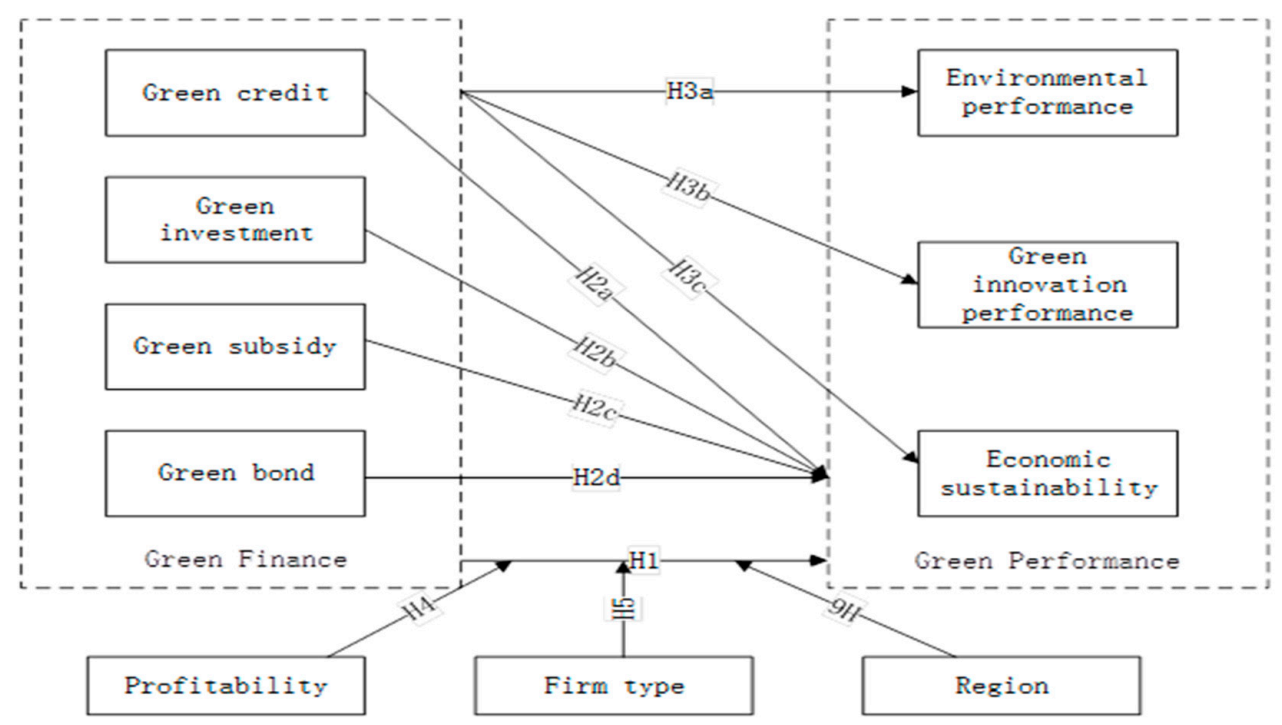

Figure 1. Proposed research model.

\section{Material and Method}

\subsection{Context Selection}

Empirical research on the relation of the system of green finance and enterprise green performance is characterized by a large amount of small sample size field studies that find many controversial conclusions. As a result, generalizable findings are limited from those empirical studies due to the underlying assumptions are based on various criteria (e.g., profitability, region, and industry) and different period.

However, meta-analysis can be used to integrate the data collected in different research hypotheses and different periods. Recently, meta-analysis shows greater achievements in the literature review as a new methodology that combines several results of empirical studies with research hypotheses [54]. It is an extremely valuable tool for summarizing research that contributes to quantitatively $[55,56]$. 
The value of this research method reflects in two aspects; on the one hand, it synthesizes complicated abundant empirical results when the role of a specific set of variables can be explored simultaneously. Hence, meta-analysis can establish an important methodological tool to integrate many quantitative outcomes of primary works. In this way, after combining the results of these studies in a simple assessment, researchers can test their hypotheses, which are difficult to test by using normal methods, and then obtain credible conclusions.

\subsection{Study Selection Process}

In order to select relevant studies, this study primarily conducted computerized keyword searches in the databases Web of Science, Google Scholar, Science Direct, Ebsco, Elsevier, and Springer before Dec 2019. The authors searched by the combination of the following keywords: "green finance" OR "green credit" OR "green investment" OR "green bond" OR "green subsidy", AND "enterprises green performance" OR "environmental performance" OR "green innovation performance" OR "economic sustainability". These keywords had to appear in any field except for the complete text. In order to avoid omissions, the research results published by scholars in this field and closely related to this study were searched one by one, and relevant literature was further searched from the references collected. Besides, the authors manually searched in the most important and relevant journals, such as the Journal of Cleaner Production and Sustainability. This produced 2821 results at the beginning, but many of them are not based on empirical research. To eliminate the heterogeneity of sample selection and data processing, data need to be uniformly coded to further screen data and exclude data that are not suitable for meta-analysis.

The main filter criteria are as follows: (1) the object of research should be an enterprise; (2) the research should be empirical research, excluding case analysis and literature review; (3) Pearson correlation coefficient and sample sizes need to be reported, or the effect value ( $\mathrm{t}$ or standard error) can be converted into Pearson correlation coefficient. Based on this, 30 independent empirical studies were finally obtained, and the sample size is 62051 . Among them, 12 out of 30 samples focus on green credit, 7 samples focus on green investment, 5 samples focus on green bond, 4 samples focus on green subsidy, and 2 samples focus on green finance.

\subsection{Coding for Studies}

Governments and financial institutions have conducted a lot of theoretical research and practical exploration and established a relatively complete support system for green finance, including green credit, green investment, green bonds, and green subsidy. Thus, the article category of green finance can be measured as green credit, green investment, green bonds, and green subsidy. However, green finance effect on different dimensions of green performance, so green performance was also coded into three categories: environmental performance, green innovation performance, and economic sustainability.

Considering different variables may have the same meaning in empirical studies, and different dimensions of green performance contain various indicators, the three dimensions of green performance was coded as follows: environmental performance was coded as managerial concern for the environment, green scale efficiency, recycling program efficiency; green innovation performance was coded as cleaner production technology, green innovation tendency, the technical level of green innovation, green technology innovation; economic sustainability was coded as green economy development index, renewable energy investment efficiency, green investment divided by sales, green loan ratio, green bond yields, green innovation investment.

If the studies used the same sample of firms, this paper included the sample only once so that can avoid biases because of the overrepresentation of specific samples. If studies based on the same sample reported different effect sizes because of the different measurements and performance, this paper calculated the average effect size and included each sample once according to the average effect size. In addition, this article coded three moderators: profitability, industry, and region. 


\subsection{Statistical Analysis}

This article uses Comprehensive Meta-Analysis Software (CMA) 2.0 for meta-analysis and chooses the method developed by Hunter and Schmidt to conduct the statistical analysis [57]. The statistical test values such as R-value, $t$-value, or standard error in all included research results were converted into Pearson correlation coefficient $r$ value, then the $r$ value was transformed by Fisher, and the obtained Fisher's $Z$ was taken as the final effect value. The extraction and coding of the original data were completed by two researchers independently, and the input results of the original data were cross-checked one by one, and the coincidence rate was $90.5 \%$ after the first coding. The difference was corrected by reviewing the original text and discussion. Table 1 shows the 30 independent samples included in our study.

Table 1. Overview of Studies.

\begin{tabular}{|c|c|c|c|c|c|c|}
\hline Sr. & Authors (year) & Fisher's Z & Sample Size & Measurement & Industry & Country \\
\hline 1 & Yujun Cui et al. (2018) & -0.36 & 168 & Green credit, Economic sustainability & various & China \\
\hline 2 & Haiqing Hu et al. (2018) & 0.1148 & 1470 & Green credit, Economic sustainability & energy-intensive firms & China \\
\hline 3 & Huiying Chen et al. (2019) & 0.0471 & 144 & $\begin{array}{l}\text { Green credit, Green innovation } \\
\text { performance }\end{array}$ & $\begin{array}{c}\text { environmental } \\
\text { protection companies }\end{array}$ & China \\
\hline 4 & Quan Guo et al. (2019) & 0.535 & 300 & $\begin{array}{l}\text { Green credit, Green innovation } \\
\text { performance }\end{array}$ & various & China \\
\hline 5 & Lingyun He et al. (2018) & 0.2656 & 119 & Green credit, Economic sustainability & $\begin{array}{l}\text { mining, power, and steel } \\
\text { industries }\end{array}$ & China \\
\hline 6 & $\begin{array}{l}\text { Liangcheng Wang and Yi } \\
\text { Zhu (2017) }\end{array}$ & -0.0525 & 2712 & Green credit, Economic sustainability & polluted enterprises & China \\
\hline 7 & Lingyun He et al. (2019) & -0.0149 & 150 & Green credit, Economic sustainability & $\begin{array}{l}\text { renewable energy listed } \\
\text { companies }\end{array}$ & China \\
\hline 8 & Enxan Wang et al. (2019) & -0.0227 & 7413 & Green credit, Economic sustainability & $\begin{array}{l}\text { heavily polluting } \\
\text { enterprises }\end{array}$ & China \\
\hline 9 & $\begin{array}{c}\text { Davide Forcella and Marek } \\
\text { Hudon (2016 }\end{array}$ & 0.18 & 415 & $\begin{array}{l}\text { Green credit, Environmental } \\
\text { Performance }\end{array}$ & various & Europe \\
\hline 10 & Changqing Luo (2017) & 0.055 & 254 & Green credit, Economic sustainability & $\begin{array}{l}\text { energy-saving } \\
\text { enterprises }\end{array}$ & China \\
\hline 11 & $\begin{array}{l}\text { Sumin Hu and Shulin Liu } \\
\text { (2019) }\end{array}$ & -0.8432 & 310 & $\begin{array}{l}\text { Green subsidy, Green innovation } \\
\text { performance }\end{array}$ & various & China \\
\hline 12 & Yu Bai et al. (2018) & -0.2836 & 192 & $\begin{array}{l}\text { Green subsidy, Environmental } \\
\text { Performance }\end{array}$ & energy-intensive firms & China \\
\hline 13 & Lingyun He et al. (2019) & 0.1931 & 829 & Green credit, Economic sustainability & $\begin{array}{l}\text { renewable energy } \\
\text { enterprises }\end{array}$ & China \\
\hline 14 & Feng Wang et al. (2019) & -0.0929 & 2560 & Green credit, Economic sustainability & $\begin{array}{l}\text { heavy polluting } \\
\text { industries }\end{array}$ & China \\
\hline 15 & Xuemei Xie et al. (2018) & 0.217 & 1585 & $\begin{array}{l}\text { Green subsidy, Green innovation } \\
\text { performance }\end{array}$ & $\begin{array}{l}\text { manufacturing-listed } \\
\text { firms }\end{array}$ & China \\
\hline 16 & Yu Bai et al. (2019) & 0.3881 & 527 & $\begin{array}{l}\text { Green subsidy, Green innovation } \\
\text { performance }\end{array}$ & energy-intensive firms & China \\
\hline 17 & Zhiyong Li et al. (2019) & -0.163 & 114 & Green bond, Economic sustainability & various & China \\
\hline 18 & $\begin{array}{l}\text { Dragon Yongjun Tang and } \\
\text { Yupu Zhang (2018) }\end{array}$ & -0.2452 & 1510 & Green bond, Economic sustainability & various & 28 countries \\
\hline 19 & Chuang He et al. (2016) & 0.0142 & 810 & $\begin{array}{l}\text { Green finance, Green innovation } \\
\text { performance }\end{array}$ & various & China \\
\hline 20 & $\begin{array}{l}\text { Xiang Deng and Junyu Lu } \\
\text { (2017) }\end{array}$ & -0.4185 & 576 & $\begin{array}{l}\text { Green finance, Environmental } \\
\text { Performance }\end{array}$ & Food companies & China \\
\hline 21 & Mingfeng Tang (2017) & 0.71 & 752 & $\begin{array}{l}\text { Green investment, Environmental } \\
\text { Performance }\end{array}$ & manufacturing firms & China \\
\hline 22 & $\begin{array}{l}\text { Juriah Conding and Nurul } \\
\text { Fadly Habidin (2012) }\end{array}$ & 0.53 & 344 & $\begin{array}{l}\text { Green investment, Green } \\
\text { Performance }\end{array}$ & Automotive Industry & Malaysian \\
\hline 23 & Juan C. Reboredo (2018) & 0.89 & 337 & Green bond, Economic sustainability & various & 37 countries \\
\hline 24 & Thomas E. Schneider (2011) & 0.435 & 244 & Green bond, Economic sustainability & $\begin{array}{l}\text { Pulp and Paper and } \\
\text { Chemical Industries }\end{array}$ & the U.S. \\
\hline 25 & $\begin{array}{l}\text { Gianfranco Gianfrate and } \\
\text { Mattia Peri (2019) }\end{array}$ & -0.2953 & 121 & Green bond, Economic sustainability & various & Europe \\
\hline 26 & Robert D. Klassen (2016) & 0.11 & 93 & $\begin{array}{l}\text { Green investment, Environmental } \\
\text { Performance }\end{array}$ & manufacturing firms & Canada \\
\hline 27 & $\begin{array}{l}\text { Roberto Antonietti and } \\
\text { Alberto Marzucchi (2014) }\end{array}$ & 0.13 & 1280 & $\begin{array}{c}\text { Green investment, Economic } \\
\text { sustainability }\end{array}$ & manufacturing firms & Italy \\
\hline 28 & Chao Tong et al. (2019) & 0.412 & 353 & $\begin{array}{c}\text { Green investment, Economic } \\
\text { sustainability }\end{array}$ & $\begin{array}{c}\text { environmental } \\
\text { protection companies }\end{array}$ & China \\
\hline 29 & Sanja Pekovic et al. (2018) & -0.01 & 16088 & $\begin{array}{c}\text { Green investment, Economic } \\
\text { sustainability }\end{array}$ & various & French \\
\hline 30 & Minna Saunila et al. (2018) & 0.229 & 139 & $\begin{array}{c}\text { Green investment, Economic } \\
\text { sustainability }\end{array}$ & $\begin{array}{l}\text { horse industry } \\
\text { companies }\end{array}$ & Finland \\
\hline
\end{tabular}




\section{Results and Discussion}

\subsection{Test for Publication Bias}

Before conducting a meta-analysis, the first problem to be solved is publication bias. Publication bias refers to a kind of bias that occurs when the results of experiments or research influence the decision to publish. Publication bias is also defined as "when studies with positive findings are more likely to be published - and they tend to be published faster — than studies with negative findings" [58]. A funnel plot was constructed to assess whether publication bias could be a threat to the validity of the result of the meta-analysis. Figure 2 shows the funnel plot of the 47 effect sizes. Obviously, the distribution concentrates mostly at the top of the funnel plot and close to the average. However, the funnel plot below does not show a clear asymmetry on the right side. Moreover, there still are some studies that deviate from the average effect sizes. Thus, the possibility of publication bias in this study is very low.

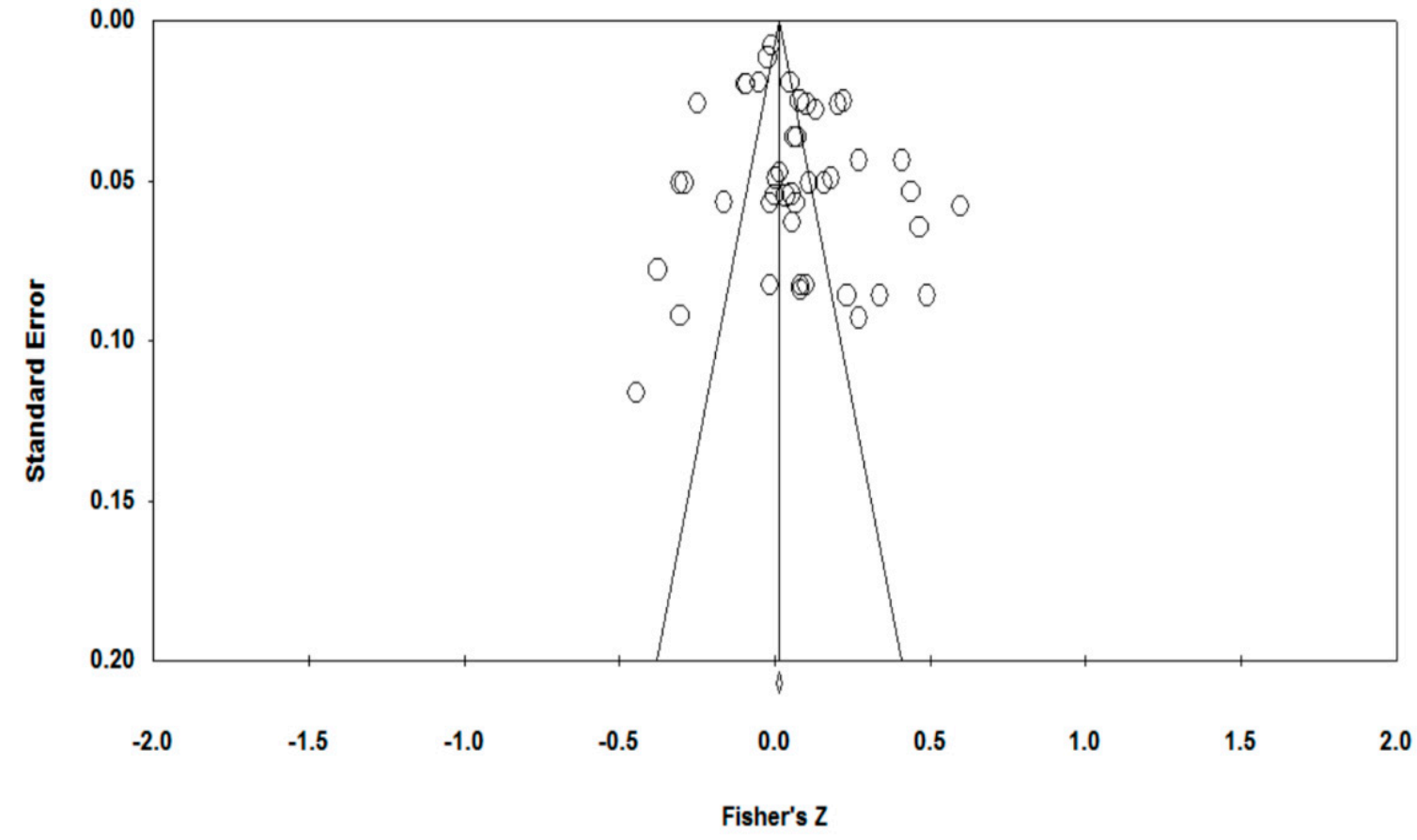

Figure 2. Funnel Plot of Standard Error by Fisher's Z.

\subsection{Test of Heterogeneity}

The heterogeneity test is a key step in the synthesis of the global effect value from the effective value of a single study. Heterogeneity in meta-analysis refers "to the variation in study outcomes between studies" [59]. In this paper, the $Q$ test was used to verify heterogeneity. In the meta-analysis, the values of $Q$ and I2 are generally used as the criterion to measure the heterogeneity level between effect values. When $\mathrm{Q}$ is greater than $\mathrm{df}(\mathrm{Q})$ and $\mathrm{I} 2$ is greater than $75 \%$, and the significance level is both less than 0.05 , the random effect model is generally used; otherwise, the fixed-effect model is used. The findings for each of the relationship considered in the meta-analysis are shown in Table 2. The overall relationship between research variables has an average effect size of 0.13 for the 47 effect sizes in the sample, representing 62051 organizations. As per the results from Table 2, this study rejected the null hypothesis of homogeneity $\left(\mathrm{I}^{2}=97.81 \%>75 \%\right)$. Although the overall effect size $(0.136)$ is a weak correlation, it still can be considered significant for practical purposes $(>0.1)$, as suggested by [60]. Therefore, the random effect model is used in this study, and the H1 is supported. 


\subsection{Bivariate Meta-Analytical Results Analysis}

Table 3 reflects the overall relationship and correlation results between the two research variables that may affect the green finance system. The four products measures have a huge difference in their effect size; in detail, green investment is the largest (0.357) while green subsidy is the smallest (0.003). However, the green subsidy and green bond are statistically insignificant for enterprise green performance because of the $95 \%$ confidence interval. That is probably on account of the small sample, which is 9 and 5, respectively. According to the Cohen's [60] scale for social science research, correlations with values close to $0.2,0.5$, and 0.8 correspond to weak, moderate, and strong effect sizes. Thus, green investment has a moderate correlation with enterprise green performance, while green credit has a weak relationship. As a result, hypothesis $2 a-d$ is accepted.

Table 2. Fixed effects and random effects meta-analysis of the relationship between green finance and green performance.

\begin{tabular}{|c|c|c|c|c|c|c|c|c|c|c|}
\hline \multirow{2}{*}{ Model } & \multirow{2}{*}{$\mathbf{n}$} & \multirow{2}{*}{ k } & \multirow{2}{*}{$\mathrm{Z}$} & \multirow{2}{*}{ Effect Size } & \multicolumn{2}{|c|}{ 95\% Confidence Intervals } & \multicolumn{4}{|c|}{ Heterogeneity } \\
\hline & & & & & Lower Limit & Upper Limit & $\mathrm{Q}$ & $\mathrm{df}(Q)$ & $\mathbf{P}$ & $\mathrm{I}^{2}(\%)$ \\
\hline $\begin{array}{c}\text { Fixed } \\
\text { Random }\end{array}$ & 62051 & 47 & $\begin{array}{c}10.113 \\
4.561\end{array}$ & $\begin{array}{l}0.051 \\
0.136\end{array}$ & $\begin{array}{l}0.041 \\
0.078\end{array}$ & $\begin{array}{l}0.033 \\
0.193\end{array}$ & 2105.999 & 46 & 0.000 & 97.816 \\
\hline
\end{tabular}

Table 3. Relationship between the four dimensions of GF and GP.

\begin{tabular}{|c|c|c|c|c|c|c|c|c|c|c|}
\hline \multirow{2}{*}{ Relationship } & \multirow{2}{*}{$\mathbf{n}$} & \multirow{2}{*}{$\mathbf{k}$} & \multirow{2}{*}{$\mathrm{Z}$} & \multirow{2}{*}{ Effect Size } & \multicolumn{2}{|c|}{ 95\% Confidence Intervals } & \multicolumn{4}{|c|}{ Heterogeneity } \\
\hline & & & & & Lower Limit & Upper Limit & $\mathbf{Q}$ & $\mathrm{df}(\mathrm{Q})$ & $\mathbf{P}$ & $\mathrm{I}^{2}(\%)$ \\
\hline Green credit-GP & 33553 & 20 & 2.016 & 0.184 & 0.005 & 0.352 & 3060.780 & 19 & 0.000 & 99.379 \\
\hline Green investment-GP & 20079 & 10 & 3.807 & 0.375 & 0.189 & 0.535 & 721.349 & 9 & 0.000 & 98.752 \\
\hline Green subsidy-GP & 5420 & 9 & 0.020 & 0.003 & -0.274 & 0.279 & 806.351 & 8 & 0.000 & 99.008 \\
\hline Green bond-GP & 2326 & 5 & 0.644 & 0.231 & -0.446 & 0.740 & 825.485 & 4 & 0.000 & 99.515 \\
\hline
\end{tabular}

Table 4 below shows the influence of green performance type on the two research variables. All four green performance types are statistically significant, but their effect size is not strong enough $(<0.5)$. To be specific, environmental performance is higher than the others $(0.415>0.185,0.038)$. These findings support hypothesis $3 \mathrm{a}-\mathrm{d}$.

Table 4. Relationship between GF and four dimensions of GP.

\begin{tabular}{|c|c|c|c|c|c|c|c|c|c|c|}
\hline \multirow{2}{*}{ Relationship } & \multirow{2}{*}{$\mathbf{n}$} & \multirow{2}{*}{ K } & \multirow{2}{*}{$\mathrm{Z}$} & \multirow{2}{*}{ Effect Size } & \multicolumn{2}{|c|}{ 95\% Confidence Intervals } & \multicolumn{4}{|c|}{ Heterogeneity } \\
\hline & & & & & Lower Limit & Upper Limit & $\mathbf{Q}$ & $\mathrm{df}(\mathrm{Q})$ & $\mathbf{P}$ & $I^{2}(\%)$ \\
\hline $\begin{array}{l}\text { GF-Environmental } \\
\text { performance }\end{array}$ & 2196 & 8 & 1.155 & 0.415 & 0.298 & 0.831 & 2162.197 & 7 & 0.000 & 99.767 \\
\hline $\begin{array}{l}\text { GF-Green innovation } \\
\text { performance }\end{array}$ & 3345 & 10 & 1.097 & 0.185 & 0.146 & 0.478 & 820.371 & 9 & 0.000 & 98.903 \\
\hline $\begin{array}{l}\text { GF-Economic } \\
\text { sustainability } \\
\text { performance }\end{array}$ & 51786 & 23 & 1.601 & 0.038 & 0.008 & 0.084 & 479.105 & 22 & 0.000 & 95.408 \\
\hline
\end{tabular}

\subsection{Moderation Analysis}

Table 5 shows the results of moderators of meta-analysis. The first group of moderators regards to profitability, both the two measurement-ROA and ROE are statistically significant, and their effect size show a weak correlation $(<0.2)$, which is 0.017 and 0.080 , respectively. However, these effect sizes are both smaller than the overall effect size (0.136), and they are not strong enough $(>0.1)$ to be considered significant for a practical purpose. Thus, hypothesis 4 is rejected. 
Table 5. Results of Moderation analysis.

\begin{tabular}{|c|c|c|c|c|c|c|c|c|c|c|}
\hline \multirow{2}{*}{ Covariate } & \multirow{2}{*}{$\mathbf{n}$} & \multirow{2}{*}{$\mathrm{k}$} & \multirow{2}{*}{$\mathrm{Z}$} & \multirow{2}{*}{ Effect Size } & \multicolumn{2}{|c|}{ 95\% Confidence Intervals } & \multicolumn{4}{|c|}{ Heterogeneity } \\
\hline & & & & & Lower Limit & Upper Limit & $\mathbf{Q}$ & $\mathrm{df}(\mathrm{Q})$ & $\mathbf{P}$ & $\mathrm{I}^{2}(\%)$ \\
\hline \multicolumn{11}{|c|}{ H4: Profitability } \\
\hline ROA & 16096 & 12 & 0.748 & 0.017 & 0.027 & 0.060 & 125.524 & 11 & 0.000 & 91.237 \\
\hline ROE & 1245 & 7 & 0.230 & 0.080 & 0.540 & 0.644 & 1130.509 & 6 & 0.000 & 99.468 \\
\hline \multicolumn{11}{|c|}{ H5: Industry } \\
\hline Environment-friendly & 1730 & 7 & 2.523 & 0.191 & 0.043 & 0.331 & 100.790 & 6 & 0.000 & 94.047 \\
\hline $\begin{array}{c}\text { Non } \\
\text { environment-friendly }\end{array}$ & 23477 & 20 & 2.377 & 0.129 & 0.024 & 0.240 & 1355.023 & 19 & 0.000 & 98.598 \\
\hline \multicolumn{11}{|c|}{ H6: Region } \\
\hline China & 21338 & 20 & 2.474 & 0.149 & 0.031 & 0.262 & 1258.380 & 19 & 0.000 & 98.490 \\
\hline $\begin{array}{l}\text { Europe and North } \\
\text { American }\end{array}$ & 18717 & 8 & 1.968 & 0.274 & 0.001 & 0.509 & 759.847 & 7 & 0.000 & 99.079 \\
\hline
\end{tabular}

In addition, the moderation of industry also shows a statistically significant relation, but the environment-friendly enterprises are slightly larger effect sizes than non-environment-friendly enterprises $(0.191>0.129)$. Therefore, hypothesis 5 is supported. The last group considers how the influence of region moderates the relationship of research variables, enterprises located in Europe and North American presents a larger effect size than those in China $(0.274>0.149)$. The correlations of the two regions are statistically significant and significant enough for practical purposes $(>0.1)$. Hence, hypothesis 6 is supported.

After analyzing these results, this paper rejected $\mathrm{H} 4$ because of the insignificance for practical purposes while accepted $\mathrm{H} 5$ and H6. That is to say, the system of green finance has a significant positive impact on enterprise green performance. Further, types of green performance, firm type, and region can significantly moderate this relationship.

\subsection{Discussion}

This paper's results demonstrated that the effect of green finance on enterprise green performance is significantly positive, which in favor of the previous studies [9]. This study analyses 48 effect sizes from 30 studies by using meta-analysis. It also includes an analysis of moderating variables to reveal the natural relationship of the research variables more deeply. The findings showed that firm type and region could significantly moderate this relationship.

Firstly, our results show that the effect of green finance can positively influence enterprise green performance. In general, most enterprises can pursue profit maximization while protecting the environment and improve their green performance through environmental management practices. The results also validate the natural resource-based view and stakeholder theory. The overall effect size reflects a weak correlation, resulting from an adverse effect or even interactions between the two research variables. Besides, as various green finance regulations and products are still in their infancy, and environmental information disclosure is not mandator, enterprises are still not aware of the importance. In other words, enterprises need to improve their green financial performance by introducing environmental factors into their financial system. The emphasis on environmental factors also meets the green environmental needs of stakeholders, which can also improve enterprise green performance.

Secondly, the four green finance products refer in this article can improve enterprise performance in an environmental-friendly way. Specifically speaking, green credit and green investment significantly influence enterprise green performance while green bonds and green subsidy are not significant. This may occur due to the small sample, except that the green bond only serves low-carbon projects, which occupies a small part in the market. The green subsidy is provided by the government, which causes dependence from some enterprises; they do not actively improve the level of environmental protection technology to promote sustainable development. 
Thirdly, green finance has more influence on environmental performance than green innovation performance and economic sustainability performance. This supports the neoclassical theory of Walley and Whitehead; environmental regulation produces extra fees so that financial performance may decrease [32]. Green finance helps enterprises solve the finance constraint for ecological innovation investment, but the widespread collusion of local governments, banks, and corporations cannot guarantee this fund flows [37]. Inadequate supervision reduces green innovation motivation, owing to low economic sustainability performance and green innovation performance.

Finally, firm type and region moderate the research relationship while profitability cannot. Profitability cannot affect the research relationship probably because higher profit means higher production, leading to more pollution. Compared with non-environmental-friendly enterprises, environmental-friendly enterprises have a better moderate effect. Nowadays, non-environmental-friendly enterprises have mainly consisted of high-energy intensive and labor-intensive industries; they still occupy an irreplaceable economic development position, which weakens the feasibility of green finance policies. Moreover, companies in developed countries have better green performance, which is attributed to their earlier practice in green finance, higher economic development, and more advanced green production technology.

\section{Conclusions, Implications, and Future Research Directions}

\subsection{Conclusions}

Prior studies have controversial findings of the effect of green finance on the enterprise green performance. Therefore, this study used meta-analysis to probe a significant effect of green finance on enterprise green performance using 30 empirical studies. It also found that firm type and region can moderate this relationship. Regarding the four green finance indicators, the influence of green investment on green performance is more obvious than green credit. However, the green bond and green subsidy have no significant effect on green performance. On the other hand, the findings demonstrate that green finance has more influence on environmental performance than green innovation performance and economic sustainability performance. It also proves that firm type and region can moderate this relationship while profitability cannot.

\subsection{Research Implications}

Firstly, the theoretical contributions in this study clarify the meaning of green finance and the enterprise green performance based on the existing research. It integrates several commonly used green financial indicators and green performance indicators and finds that there is a positive correlation between them. This finding is an important summary of the existing research, which lays a foundation for further research on how the two research variables affect each other.

Secondly, based on the correlation between the four dimensions of green finance and enterprise green performance, this study reclassifies the dimensions of green performance based on existing literature, and the three dimensions are explained in detail. According to [61], green performance research is still at an early stage, and there is an imperative need to enrich the literature in this field. With the rise of green finance research, the research on the relationship between green finance and enterprise green performance is also increasing. However, there is no unified conclusion on the definition and dimension of enterprise green performance. This paper provides a certain basis for it.

\subsection{Limitations and Future Extensions}

This study still has some limitations that result from the inherent shortcomings of meta-analysis as described by [62]. On the one hand, the meta-analysis process ignores the problem of endogeneity. On the other hand, meta-analysis only included studies that reported Pearson correlation coefficients, which lost some samples, and the elimination of samples because of unavailable effect size may influence the relationship in this paper. Although it finds a significant positive relationship between the 
system of green finance and enterprise green performance, the sample size involving some moderator analysis is small. Thus, conclusions based on these variables may exist bias.

Furthermore, this paper ignored the data from cross-industry enterprises, which may lead to inaccurate conclusions. Further research should continue extending the understanding of the system of green finance and enterprise green performance's link. It is meaningful to research how the moderators influence this link. Future research can also consider the other moderators (such as firm size, liquidity, leverage, etc.) which are not mentioned in this article.

Author Contributions: Conceptualization, H.X.; methodology, H.X.; software, S.L., and J.Z.; validation, S.L, and F.S.; formal analysis, H.X.; investigation, X.L.; resources, Q.M.; data curation, F.S.; writing-original draft preparation, H.X.; writing-review and editing, F.S.; visualization, F.S. and J.Z.; supervision, Q.M. and X.L.; project administration, Q.M..; funding acquisition, Q.M. All authors have read and agreed to the published version of the manuscript.

Funding: This work was supported by the National Nature Science Foundation of China (71874072), National Natural Science Foundation of China (72004081), and also by the China Postdoctoral Science Foundation (2020M671378).

Conflicts of Interest: The authors declare no conflict of interest.

\section{References}

1. Masocha, R. Does environmental sustainability impact innovation, ecological and social measures of firm performance of SMEs? Evidence from South Africa. Sustainability 2018, 10, 3855. [CrossRef]

2. Davenport, M.; Delport, M.; Blignaut, J.N.; Hichert, T.; van der Burgh, G. Combining theory and wisdom in pragmatic, scenario-based decision support for sustainable development. J. Environ. Plan. Manag. 2019, 62, 692-716. [CrossRef]

3. Pekovic, S.; Grolleau, G.; Mzoughi, N. Environmental investments: Too much of a good thing? Int. J. Prod. Econ. 2018, 197, 297-302. [CrossRef]

4. UK Parliament Environmental Audit Committee-Twelfth Report. Available online: https://publications. parliament.uk/pa/cm201314/cmselect/cmenvaud/191/19102.htm (accessed on 25 October 2020).

5. Berensmann, K.; Lindenberg, N. Green Finance: Actors, Challenges and Policy Recommendations; German Development Institute: Bonn, Germany, 2016.

6. Wang, Y.; Zhi, Q. The role of green finance in environmental protection: Two aspects of market mechanism and policies. Energy Procedia 2016, 104, 311-316. [CrossRef]

7. Luo, C.; Fan, S.; Zhang, Q. Investigating the influence of green credit on operational efficiency and financial performance based on hybrid econometric models. Int. J. Financ. Stud. 2017, 5, 27. [CrossRef]

8. He, L.; Zhang, L.; Zhong, Z.; Wang, D.; Wang, F. Green credit, renewable energy investment and green economy development: Empirical analysis based on 150 listed companies of China. J. Clean. Prod. 2019, 208, 363-372. [CrossRef]

9. Deng, X.; Lu, J. The environmental performance, corporate social responsibility, and food safety of food companies from the perspective of green finance. Revista Cercetare Social 2017, 58, 178-200.

10. Zhou, X.; Tang, X.; Zhang, R. Impact of green finance on economic development and environmental quality: A study based on provincial panel data from China. Environ. Sci. Pollut. Res. 2020, 27, 19915-19932. [CrossRef] [PubMed]

11. Olsthoorn, X.; Tyteca, D.; Wehrmeyer, W.; Wagner, M. Environmental indicators for business: A review of the literature and standardisation methods. J. Clean. Prod. 2001, 9, 453-463. [CrossRef]

12. Lin, B.; Chen, $X$. Environmental regulation and energy-environmental performance-Empirical evidence from China's non-ferrous metals industry. J. Environ. Manag. 2020, 269, 110722. [CrossRef]

13. Bai, Y.; Hua, C.; Jiao, J.; Yang, M.; Li, F. Green efficiency and environmental subsidy: Evidence from thermal power firms in China. J. Clean. Prod. 2018, 188, 49-61. [CrossRef]

14. Vittorio, A. G20 Talks on Green Finance Could Cement China, U.S. Legacy on Climate Change. In Proceedings of the G20 Summit, Hangzhou, China, 4-5 September 2016. 
15. Höhne, B.N.; Khosla, S.; Fekete, H.; Gilbert, A. Mapping of Green Finance Delivered by IDFC Members in 2011 Mapping of Green Finance Delivered by IDFC Members in 2011. 2012. Available online: http://wwwidfc.org/Downloads/Publications/01_green_finance_mappings/IDFC_Green_Finance_ Mapping_Report_2012_14-06-12.Pdf (accessed on 16 August 2020).

16. Lindenberg, N. Definition of Green Finance; German Development Institute: Bonn, Germany, 2014.

17. International Finance Corporation (IFC). IFC Annual Report 2017: Creating Markets; International Finance Corporation: Washington, DC, USA, 2017.

18. Falcone, P.M.; Sica, E. Assessing the opportunities and challenges of green finance in Italy: An analysis of the biomass production sector. Sustainability 2019, 11, 517. [CrossRef]

19. Soundarrajan, P.; Vivek, N. Green finance for sustainable green economic growth in india. Agric. Econ. 2016, 62, 35-44. [CrossRef]

20. $\mathrm{Xu}, \mathrm{X} . ; \mathrm{Li}, \mathrm{J}$. Asymmetric impacts of the policy and development of green credit on the debt financing cost and maturity of different types of enterprises in China. J. Clean. Prod. 2020, 264, 121574. [CrossRef]

21. Eyraud, L.; Clements, B.; Wane, A. Green investment: Trends and determinants. Energy Policy 2013, 60, 852-865. [CrossRef]

22. Antonietti, R.; Marzucchi, A. Green tangible investment strategies and export performance: A firm-level investigation. Ecol. Econ. 2014, 108, 150-161. [CrossRef]

23. Dröge, S.; Schröder, P.J.H. How to turn an industry green: Taxes versus subsidies. J. Regul. Econ. 2005, 27, 177-202. [CrossRef]

24. Xie, X.; Zhu, Q.; Wang, R. Turning green subsidies into sustainability: How green process innovation improves firms' green image. Bus. Strategy Environ. 2019, 28, 1416-1433. [CrossRef]

25. Amores-Salvadó, J.; De Castro, G.M.; Navas-López, J.E. Green corporate image: Moderating the connection between environmental product innovation and firm performance. J. Clean. Prod. 2014, 83, 356-365. [CrossRef]

26. Chang, Y.T. Environmental efficiency of ports: A data envelopment analysis approach. Marit. Policy Manag. 2013, 40, 467-478. [CrossRef]

27. Lirn, T.C.; Wu, Y.C.J.; Chen, Y.J. Green performance criteria for sustainable ports in Asia. Int. J. Phys. Distrib. Logist. Manag. 2013, 43, 427-451. [CrossRef]

28. Tseng, M.L.; Lan, L.W.; Wang, R.; Chiu, A.; Cheng, H.P. Using hybrid method to evaluate the green performance in uncertainty. Environ. Monit. Assess. 2011, 175, 367-385. [CrossRef] [PubMed]

29. Abbas, J. Impact of total quality management on corporate green performance through the mediating role of corporate social responsibility. J. Clean. Prod. 2020, 242, 118458. [CrossRef]

30. Schiederig, T.; Tietze, F.; Herstatt, C. Green innovation in technology and innovation management-An exploratory literature review. R D Manag. 2012, 42, 180-192. [CrossRef]

31. Huang, X.X.; Hu, Z.P.; Liu, C.S.; Yu, D.J.; Yu, L.F. The relationships between regulatory and customer pressure, green organizational responses, and green innovation performance. J. Clean. Prod. 2016, 112, 3423-3433. [CrossRef]

32. Walley, N.; Whitehead, B. It's not easy being green. In Corporate Environmental Responsibility; Taylor and Francis: London, UK, 2017; ISBN 9781351948562.

33. Porter, M.E. America's green strategy. Sci. Am. 1991, 264, 193-246.

34. Hart, S.L.; Dowell, G. A natural-resource-based view of the firm: Fifteen years after. J. Manag. 2011, 37, 1464-1479.

35. Surroca, J.; Tribó, J.A.; Waddock, S. Corporate responsibility and financial performance: The role of intangible resources. Strateg. Manag. J. 2010, 31, 463-490. [CrossRef]

36. Buysse, K.; Verbeke, A. Proactive environmental strategies: A stakeholder management perspective. Strateg. Manag. J. 2003, 24, 453-470. [CrossRef]

37. Wang, E.; Liu, X.; Wu, J.; Cai, D. Green credit, debt maturity and corporate investment-evidence from China. Sustainability 2019, 11, 583. [CrossRef] 
38. Guo, Q.; Zhou, M.; Liu, N.; Wang, Y. Spatial effects of environmental regulation and green credits on green technology innovation under low-carbon economy background conditions. Int. J. Environ. Res. Public Health 2019, 16, 3027. [CrossRef]

39. Hu, H.; Chang, C.P.; Dong, M.; Meng, W.N.; Hao, Y. Does environmental information disclosure affect the performance of energy-intensive firms' borrowing ability? Evidence from China. Energy Environ. 2018, 29, 685-705. [CrossRef]

40. Nie, P.Y.; Chen, Y.H.; Yang, Y.C.; Wang, X.H. Subsidies in carbon finance for promoting renewable energy development. J. Clean. Prod. 2016, 139, 677-684. [CrossRef]

41. Gianfrate, G.; Peri, M. The green advantage: Exploring the convenience of issuing green bonds. J. Clean. Prod. 2019, 219, 127-135. [CrossRef]

42. Fujii, H.; Iwata, K.; Kaneko, S.; Managi, S. Corporate environmental and economic performance of Japanese manufacturing firms: Empirical study for sustainable development. Bus. Strategy Environ. 2013, 22, 187-201. [CrossRef]

43. Golinska, P.; Kuebler, F. The method for assessment of the sustainability maturity in remanufacturing companies. Procedia CIRP 2014, 15, 201-206. [CrossRef]

44. Aguilera-Caracuel, J.; Ortiz-de-Mandojana, N. Green innovation and financial performance: An institutional approach. Organ. Environ. 2013, 26, 365-385. [CrossRef]

45. Hargrave, M. Return on Assets-ROA. Available online: https://www.investopedia.com/terms/r/ returnonassets.asp (accessed on 25 October 2020).

46. Hargrave, M. Return on Equity-ROE. Available online: https://www.investopedia.com/terms/r/ returnonequity.asp (accessed on 25 October 2020).

47. Helfert, E. A Financial Analysis Tools and Techniques: A Guide for Managers; McGraw-Hill: New York, NY, USA, 2001; ISBN 0071395415.

48. Jeucken, M. Sustainable Finance and Banking: The Financial Sector and the Future of the Planet; Earthscan: London, UK, 2010; ISBN 9781849776264.

49. Labatt, S.; White, R.R. Environmental Finance: A Guide to Environmental Risk Assessment and Financial Products; John Wiley \& Sons: New Jersey, NJ, USA, 2002; ISBN 3175723993.

50. Wang, L.; Zhu, Y. Green credit policy and the maturity of corporate debt. In Advances in Intelligent Systems and Computing; Springer: Singapore, 2017; Volume 502, pp. 1709-1717.

51. He, L.; Wu, C.; Yang, X.; Liu, J. Corporate social responsibility, green credit, and corporate performance: An empirical analysis based on the mining, power, and steel industries of China. Nat. Hazards 2019, 95, 73-89. [CrossRef]

52. Watkins, C. The American Heritage Dictionary of Indo-European Roots, 3rd ed.; Houghton Mifflin Harcourt: Boston, MA, USA, 2012; Volume 49.

53. Ya, W. The Overall Plan for Ecological Civilization System Reform. Available online: http://www.gov.cn/ guowuyuan/2015-09/21/content_2936327.htm (accessed on 10 September 2020).

54. Marín-Martínez, F.; Sánchez-Meca, J. Averaging Dependent Effect Sizes in Meta-Analysis: A Cautionary Note about Procedures. Span. J. Psychol. 1999, 2, 32-38. [CrossRef]

55. Eisend, M. Morality effects and consumer responses to counterfeit and pirated products: A meta-analysis. J. Bus. Ethics 2019, 154, 301-323. [CrossRef]

56. Ismagilova, E.; Slade, E.; Rana, N.P.; Dwivedi, Y.K. The effect of characteristics of source credibility on consumer behaviour: A meta-analysis. J. Retail. Consum. Serv. 2020, 53. [CrossRef]

57. Hunter, J.E.; Schmidt, F.L. Cumulative research knowledge and social policy formulation: The critical role of meta-analysis. Psychol. Public Policy Law 1996, 2, 324-347. [CrossRef]

58. Glen, S. Publication Bias: Definition, Examples. Available online: https://www.statisticshowto.com/ publication-bias/ (accessed on 25 October 2020).

59. Higgins, J.P.T.; Thompson, S.G.; Deeks, J.J.; Altman, D.G. Measuring inconsistency in meta-analyses. Br. Med. J. 2003, 327, 557-560. [CrossRef]

60. Cohen, J. Statistical Power Analysis for Behavioural Sciences; Academic Press: New York, NY, USA, 1998; ISBN 0805802835. 
61. Zhang, D.; Rong, Z.; Ji, Q. Green innovation and firm performance: Evidence from listed companies in China. Resour. Conserv. Recycl. 2019, 144, 48-55. [CrossRef]

62. Rosenthal, R.; DiMatteo, M.R. Meta-analysis: Recent developments in quantitative maethods for literature reviews. Annu. Rev. Psychol. 2001, 52, 59-82. [CrossRef] [PubMed]

Publisher's Note: MDPI stays neutral with regard to jurisdictional claims in published maps and institutional affiliations.

(C) 2020 by the authors. Licensee MDPI, Basel, Switzerland. This article is an open access article distributed under the terms and conditions of the Creative Commons Attribution (CC BY) license (http://creativecommons.org/licenses/by/4.0/). 